(2) Open Access Full Text Article

ORIGINAL RESEARCH

\title{
Immunohistochemical Analysis of PGC-I $\alpha$ and ERR $\alpha$ Expression Reveals Their Clinical Significance in Human Ovarian Cancer
}

This article was published in the following Dove Press journal: OncoTargets and Therapy

\author{
Xiqi Huang $\mathbb{D}^{\prime}$ \\ Guanyu Ruan (iD) ${ }^{1,2}$ \\ Guifen Liu iD' \\ Yuqin Gao' \\ Pengming Sun (D) 1,2 \\ 'Laboratory of Gynecologic Oncology, \\ Fujian Provincial Maternity and Children's \\ Health Hospital, Affiliated Hospital of Fujian \\ Medical University, Fuzhou, People's \\ Republic of China; ${ }^{2}$ Key Laboratory of \\ Women and Children's Critical Diseases \\ Research, Fujian Provincial Maternity and \\ Children's Health Hospital, Affiliated \\ Hospital of Fujian Medical University, \\ Fuzhou, People's Republic of China
}

Purpose: Peroxisome proliferator-activated receptor gamma coactivator 1-alpha (PGC-1 $\alpha$ ) and estrogen-related receptor alpha $(\mathrm{ERR} \alpha)$ play a vital role in various human cancers. The purpose of this study was to investigate whether the PGC- $1 \alpha / \mathrm{ERR} \alpha$ axis could serve as an effective prognostic marker in ovarian cancer (OC).

Patients and Methods: We investigated the expression of both PGC- $1 \alpha$ and ERR $\alpha$ in 42 ovarian cancer and 31 noncancerous ovarian samples by immunohistochemistry (IHC). The relationship between the expression of PGC-1 $\alpha$ and ERR $\alpha$ in OC and the clinical characteristics of patients was evaluated. In addition, data from the Human Protein Atlas (HPA) database were collected to validate the prognostic significance of PGC- $1 \alpha$ and ERR $\alpha$ mRNA expression in OC.

Results: PGC- $1 \alpha$ and ERR $\alpha$ showed notably higher expression in OC tissues than in noncancerous tissues $(\mathrm{P}=0.0059, \mathrm{P}=0.002)$. Moreover, in patients with $\mathrm{OC}$, high $\mathrm{ERR} \alpha$ and $\mathrm{PGC}-1 \alpha / \mathrm{ERR} \alpha$ expression significantly correlated with tumor differentiation $(\mathrm{P}=0.027$; $\mathrm{P}=0.04)$, lymph node status $(\mathrm{P}=0.023 ; \mathrm{P}=0.021), \mathrm{CA} 125 \quad(\mathrm{P}=0.036 ; \mathrm{P}=0.021)$, and HE4 $(\mathrm{P}=0.021 ; \mathrm{P}=0.05)$, while high $\mathrm{PGC}-1 \alpha$ expression was only significantly associated with tumor differentiation $(\mathrm{P}=0.029)$. The combined analysis of high PGC- $1 \alpha$ and ERR $\alpha$ expression revealed a tendency towards poor cancer-specific survival $(\mathrm{P}=0.1276)$.

Conclusion: PGC- $1 \alpha$ and ERR $\alpha$ are overexpressed in OC and might be significant prognostic factors for this cancer.

Keywords: prognostic significance, estrogen-related receptor alpha, immunohistochemistry, ovarian malignance, peroxisome proliferator-activated receptor gamma coactivator 1-alpha

\section{Introduction}

Ovarian cancer is one of the most fatal malignancies in women and poses a serious threat to women's health. Despite some progress achieved with extensive clinical and basic research, the etiology and tumorigenesis of $\mathrm{OC}$ are not fully understood. Tumor heterogeneity leads to different stages and characteristics of disease development. Different molecular drivers may exist in patients with OC at the same stage, leading to heterogeneous treatment responses and prognosis. ${ }^{1}$ It is therefore urgent to investigate the molecular markers underlying ovarian cancer and identify novel therapeutic targets for OC treatment.

Estrogen-related receptor alpha (ESRRA, also known as ERR $\alpha$ ), a member of the ligand-independent orphan nuclear receptor superfamily, is expressed primarily in tissues with high metabolic demand and controls the expression of genes involved in
Correspondence: Pengming Sun Key Laboratory of Women and Children's Critical Diseases Research, Fujian Provincial Maternity and Children's Health Hospital, Affiliated Hospital of Fujian Medical University, No. 18. Daoshan

Road, Gulou District, Fuzhou, 35000

Fujian, People's Republic of China

Tel +86 59l 87558732

Fax +865918755 1247

Email sunfemy@hotmail.com
OncoTargets and Therapy 2020:13 |3055-13062

13055

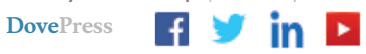

http://doi.org/10.2147/0TT.S288332 (c) (i) (5) 2020 Huang et al. This work is published and licensed by Dove Medical Press Limited. The full terms of this license are available at https:///www.dovepress.com/terms. (c) ${ }_{\mathrm{BY}} \mathrm{NC}$ php and incorporate the Creative Commons Attribution - Non Commercial (unported, v3.0) License (http://creativecommons.org/licenses/by-nc/3.01). By accessing the work you hereby accept the Terms. Non-commercial uses of the work are permitted without any further permission from Dove Medical Press Limited, provided the work is properly attributed. For permission for commercial use of this work, please see paragraphs 4.2 and 5 of our Terms (https://www.dovepress.com/terms.php). 
cellular energy metabolism. ${ }^{2-4}$ Notably, ERR $\alpha$ has been reported to be overexpressed in breast, colon, and endometrial cancers, and its overexpression is related to poor prognosis. $^{5-8}$ Our prior studies have demonstrated that the mRNA levels of ERR $\alpha$ increase with the clinical stage of ovarian cancer, thus suggesting $\mathrm{ERR} \alpha$ as a prognostic factor for ovarian cancer. ${ }^{7}$ ERR $\alpha$ also has potential diagnostic and therapeutic value in OC. ERR $\alpha$ activity highly relies on the presence of coregulatory proteins, most notably that of peroxisome proliferator-activated receptor gamma coactivator 1-alpha (PPARGC1A, also known as PGC-1 $\alpha$ ). ${ }^{9,10}$ The PGC-1 $\alpha / E R R \alpha$ axis has been implicated in controlling the expression of metabolic gene networks and mitochondrial biogenesis. ${ }^{11,12}$ Accumulating evidence suggests that the PGC- $1 \alpha /$ ERR $\alpha$ axis plays a vital role in various cancer development and progression, which are accompanied by metabolic dysfunction. ${ }^{10,13}$ Our recent study indicated that PGC- $1 \alpha$ and ERR $\alpha$ positively correlate with more advanced myometrial invasion in endometrial cancer, and were robust predictors for myometrial invasion. ${ }^{14}$

Currently, the suitability of PGC- $1 \alpha$ and ERR $\alpha$ as biomarkers in OC tissues has not been thoroughly examined. To investigate whether the PGC- $1 \alpha / \mathrm{ERR} \alpha$ axis acts as an effective prognostic marker for patients with $\mathrm{OC}$, we detected the expression of these proteins in human $\mathrm{OC}$ tissues using immunohistochemistry and investigated their clinical significance in OC.

\section{Patients and Methods}

\section{The HPA Database}

First, we explored mRNA expression of PGC- $1 \alpha$ and ERR $\alpha$ in normal tissues and ovarian cancer tissues from the HPA database (https://www.proteinatlas.org/). The HPA database provides abundant transcriptome and proteome data in specific human tissues through RNA-sequencing analysis and immunohistochemistry analysis. ${ }^{15,16}$ In addition, we analyzed the prognostic significance of PGC- $1 \alpha$ and $\mathrm{ERR} \alpha \mathrm{mRNA}$ in patients with OC.

\section{Patients and Tissue Samples}

A total of 42 OC and 31 noncancer ovarian samples with related clinical data were obtained for immunohistochemistry from patients who received surgical therapy between September 2012 and April 2019. None of the patients received preoperative chemotherapy or radiotherapy. This study was approved by the Ethics Committee of Fujian Maternity and Child Health Hospital affiliated with Fujian
Medical University (approval number 2013-004), and performed in compliance with the Declaration of Helsinki. Informed consent was obtained from all patients. The patients were followed up postoperatively by their surgeons at 3-month intervals for 5 years and yearly thereafter. Overall survival (OS) was defined as the interval between surgery and mortality or the last follow-up (censored data for living patients). At the end of the follow-up period, seven patients $(16.7 \%)$ died of OC.

\section{Immunohistochemistry}

To examine the expression of PGC- $1 \alpha$ and ERR $\alpha$ in OC, we performed a tissue microarray constructed by Shanghai Zhuoli Biotechnology Co., Ltd (Zhuoli Biotechnology Co, Shanghai, China). Rabbit polyclonal anti-ERR $\alpha$ (ab93173, Abcam) and rabbit polyclonal anti-PGC-1 alpha-N-terminal (ab191838, Abcam) antibodies were used. In each case, 1-2 $\mu \mathrm{m}$-thick sections from paraffin tissue blocks were cut, dewaxed, pretreated, and transferred to glass slides using an adhesive tape transfer system, in order to conduct ultraviolet cross linkage. All reactions were performed using an automated staining device. Two pathologists independently evaluated the quantitation of immunostaining for PGC- $1 \alpha$ and ERR $\alpha$, who were blinded to patient details. The expression of PGC-1 $\alpha$ and ERR $\alpha$ in tumor parenchyma was semiquantified by immunoreactivity score (IR score) based on intensity and heterogeneity. The IR score was determined as the sum of heterogeneity and intensity. The percentage of positive cells was scored as 0 points $(0 \%), 1$ point (1-25\%), 2 points $(26-50 \%), 3$ points $(51-75 \%)$, and 4 points $(76-$ $100 \%$ ). Positive staining intensity was scored as 0 points (none), 1 point (low), 2 points (medium), and 3 points (high).

\section{Statistical Analysis}

Frequency and percentage were calculated for the classified variables. We used the Chi-square test to evaluate the differences in PGC-1 $\alpha$ and ERR $\alpha$ expression between the two groups of clinicopathological features. The comparison between IR score in cancer foci and in noncancer lesions was analyzed by Student's $t$-test. Cancer-specific survival curves were obtained using the Kaplan-Meier method and verified by the log-rank (Mantel-Cox) test. All statistical analyses were performed using SPSS 19.0 software (SPSS Inc., Chicago, IL, USA) and GraphPad Prism Version 8.0 software (GraphPad Software, Inc., La Jolla, CA, USA). All $\mathrm{P}$-values in the statistical analysis were two-tailed, and $\mathrm{P}<0.05$ was considered statistically significant. 


\section{Result}

\section{Expression and Prognostic Significance of PGC-I $\alpha$ and ERR $\alpha$ mRNA in the HPA Database}

The mRNA expression profiles retrieved from HPA (https:// www.proteinatlas.org/ENSG00000109819-PPARGC1A/tis sue, https://www.proteinatlas.org/ENSG00000173153ESRRA/tissue) revealed low mRNA expression of PGC-1 $\alpha$ and ERR $\alpha$ in normal ovarian tissues (Figure $1 \mathrm{~A}$ and $\mathrm{B}$ ). We then explored the association between mRNA expression of PGC- $1 \alpha$ and $\mathrm{ERR} \alpha$ and survival outcome in OC from the HPA database (https://www.proteinatlas. org/ENSG00000109819-PPARGC1A/pathology, https:// www.proteinatlas.org/ENSG00000173153-ESRRA/pathol ogy). As shown in Figure 1C, the 5-year OS rates in patients with high and low ERR $\alpha$ expression were $25 \%$ and $34 \%$, respectively. Patients with high ERR $\alpha$ expression had
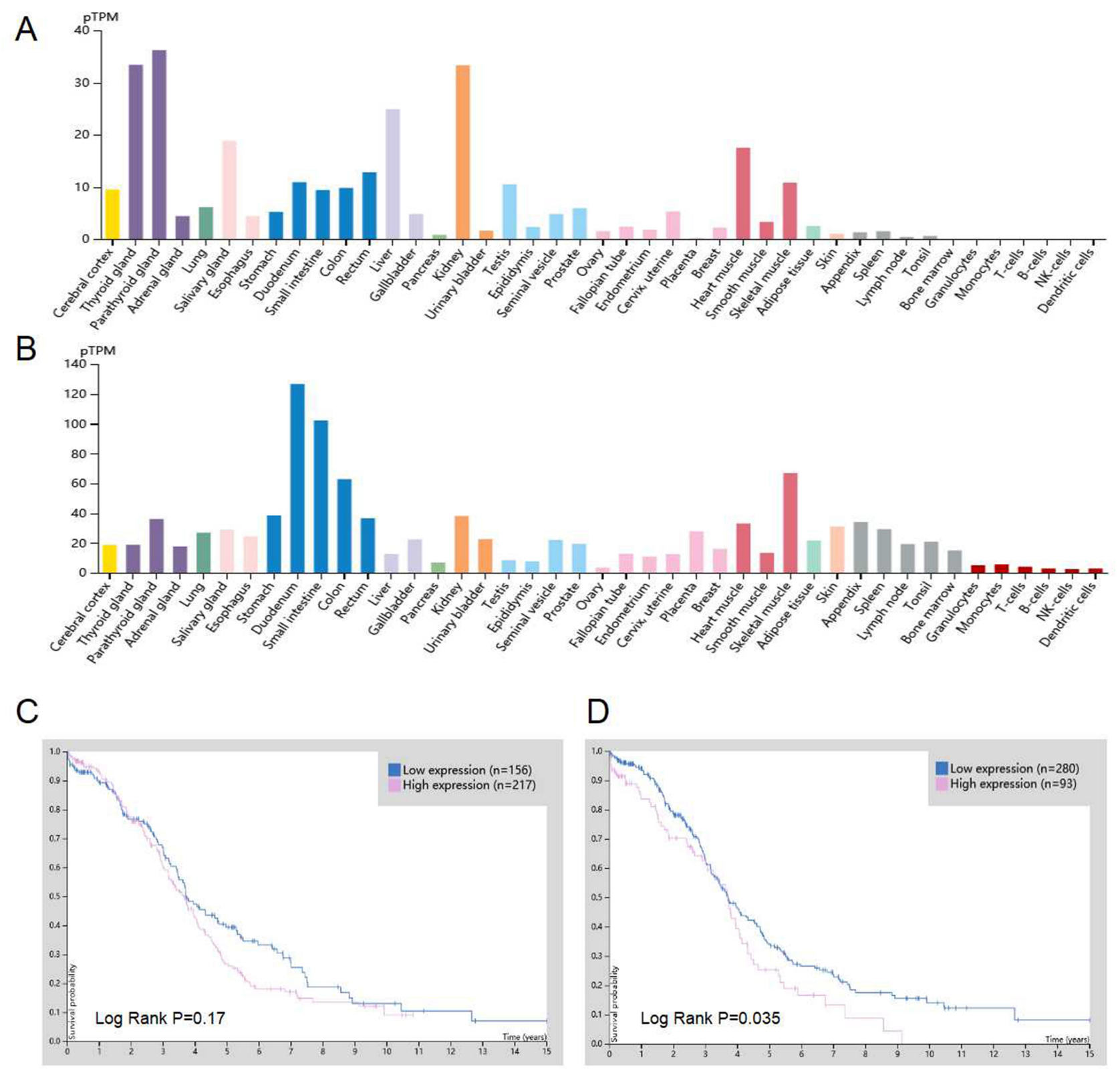

Figure I Expression and prognostic significance of PGC-I $\alpha$ and ERR $\alpha$ mRNA in HPA database. (A and B) PGC-I $\alpha$ and ERR $\alpha$ mRNA expression in different normal human tissues. (C) Patients with high PGC-I $\alpha$ mRNA expression tend to have a poorer overall rate compared with those with low PGC-I $\alpha$ mRNA expression in OC (P = 0.I7). (D) Patients with high ERR $\alpha$ mRNA expression exhibited a poorer overall rate compared with those with low ERR $\alpha \mathrm{mRNA}$ expression in OC (P=0.035). All the pictures were downloaded from HPA database.

Abbreviations: ERR $\alpha$, estrogen-related receptor $\alpha$; HPA, Human Protein Atlas; OC, ovarian cancer; PGC-I $\alpha$, peroxisome proliferator-activated receptor gamma coactivator I-alpha. 
significantly lower OS rates than those with low ERR $\alpha$ expression ( $\mathrm{P}=0.035$; Figure $1 \mathrm{D})$. The 5-year OS rates in patients with high and low PGC-1 $\alpha$ expression were $27 \%$ and 39\%, respectively. However, while patients with high PGC-1 $\alpha$ expression tended to show poor cancer-specific survival rates, this association was not significant $(\mathrm{P}=0.17$; Figure 1C).

\section{Expression of PGC-I $\alpha$ and ERR $\alpha$ in OC} Tissues

Next, we determined the protein expression of PGC-1 $\alpha$ and ERR $\alpha$ in 42 OC tissues and 31 noncancerous ovarian tissues by IHC. Statistical analysis showed that OC tissues exhibited significantly higher PGC- $1 \alpha$ and ERR $\alpha$ expression than noncancerous ovarian tissues $(\mathrm{P}=0.0059$, $\mathrm{P}=0.002$; Figure $2 \mathrm{~A}$ and $\mathrm{B}$ ). As shown in Figure $2 \mathrm{C}$, $\mathrm{ERR} \alpha$ was primarily detected in the nuclei of tumor cells, while PGC-1 $\alpha$ was mainly detected in the cytoplasm. IHC also revealed that the expression of PGC-1 $\alpha$ and $\mathrm{ERR} \alpha$ was low in noncancerous tissues, but elevated in OC tissues.

\section{Association Between PGC-I $\alpha /$ ERR $\alpha$ Expression and Clinical Parameters in OC} To investigate the clinical significance of PGC- $1 \alpha$ and ERR $\alpha$ in ovarian cancer, we analyzed the association between expression of these proteins and clinical characteristics of 42 patients with OC (Table 1). Almost all tumor foci showed IR scores $\geq 3$ and $\geq 4$ for PGC- $1 \alpha$ and ERR $\alpha$, respectively (Figure $2 \mathrm{~A}$ and $\mathrm{B}$ ). Thus, we defined an IR score of 4 and 7 as the cut-off for high PGC- $1 \alpha$ and ERR $\alpha$, respectively, in order to identify a potential correlation between PGC-1 $\alpha / E R R \alpha$ expression and patient clinical characteristics. Significant associations were identified between high ERR $\alpha$ and PGC-1 $\alpha / E R R ~ \alpha$ expression and tumor differentiation $(\mathrm{P}=0.027 ; \mathrm{P}=0.04)$, lymph node status $(\mathrm{P}=0.023 ; \mathrm{P}=0.021), \mathrm{CA} 125$ ( $\mathrm{P}=0.036$; $\mathrm{P}=0.021)$, and HE4 $(\mathrm{P}=0.021 ; \mathrm{P}=0.05)$. However, high PGC-1 $\alpha$ expression was only significantly associated with tumor differentiation $(\mathrm{P}=0.029)$.

\section{Prognostic Significance of PGC-I $\alpha$ and ERR $\alpha$ in OC}

The Kaplan-Meier estimator model was employed to evaluate the prognostic significance of PGC- $1 \alpha$ and ERR $\alpha$ expression (Figure 3). Seven (16.7\%) patients died of ovarian cancer during the follow-up period. No significant relationship was observed between expression of PGC-1 $\alpha$ and ERR $\alpha$ and cancer-specific survival rate $(\mathrm{P}=0.4736$, $\mathrm{P}=0.3119$; Figure $3 \mathrm{~A}$ and $\mathrm{B}$ ). However, combined analysis of high PGC-1 $\alpha$ and ERR $\alpha$ expression revealed a tendency towards poor cancer-specific survival $(\mathrm{P}=0.1276$; Figure 3C).

\section{Discussion}

Increasing evidence has suggested that ERR $\alpha$ promotes tumor cell proliferation, angiogenesis, metastasis, and drug resistance in various cancers. ${ }^{10,17}$ Willy et $\mathrm{al}^{18}$ and Chisamore et $\mathrm{al}^{19}$ revealed that suppression of ERR $\alpha$ blocks the cell cycle in the G1/S transition, hindering the growth of breast tumor cell lines and their tumorigenicity in vivo. Epithelial-mesenchymal transition (EMT) plays an essential role in OC cell invasion and metastasis. ${ }^{20,21}$ Wang et $\mathrm{al}^{22}$ reported that suppression of ERR $\alpha$ expression inhibits tumor metastasis and migration in OC cell lines by restraining mitochondrial activity and preventing EMT in vitro. Moreover, in an orthotopic model of OC, Lam et $\mathrm{al}^{23}$ found that inhibition of ERR $\alpha$ dramatically reduces tumor burden, ascites formation, and metastatic peritoneal nodules in vivo. Our recent research also demonstrated that inhibition of ERR $\alpha$ reduces EMT phenotypes, thereby significantly inhibiting invasion and migration in endometrial cancer cells. ${ }^{14}$ ERR $\alpha$ expression has also been associated with negative outcome in various human cancers. For example, in breast cancer, the mRNA and protein expression of ERR $\alpha$ positively correlates with node status, increased risk of recurrence, and metastatic status. ${ }^{24,25}$ Our previous studies have demonstrated that a high mRNA level of ERR $\alpha$ is associated with advanced FIGO stage and histological grade, and is thus associated with poor prognosis and shorter median overall survival time in OC. ${ }^{7}$

However, ERR $\alpha$ activity is primarily controlled by its coactivators, especially PGC- $1 \alpha$. The PGC- $1 \alpha / \mathrm{ERR} \alpha$ axis also has been implicated in regulating several genes involved in energy metabolism, and increased mRNA and protein levels of ERR $\alpha$ in tissues are accompanied by high expression of PGC- $1 \alpha^{26,27}$ Expression of PGC- $1 \alpha$ and ERR $\alpha$ is sensitive to physiological and pathological changes, which strengthens their crucial role in energy homeostasis in health and disease. ${ }^{9}$ Compounds affecting either the coactivator or the receptor could regulate signaling activity. ${ }^{9,10}$ Moreover, several studies indicate that PGC- $1 \alpha / \mathrm{ERR} \alpha$ efficiently induce vascular endothelial growth factor (VEGF), and promote angiogenesis, mitochondrial biogenesis, and OXPHOS, leading to tumor angiogenesis, invasion, and metastasis. ${ }^{28-30}$ 
A

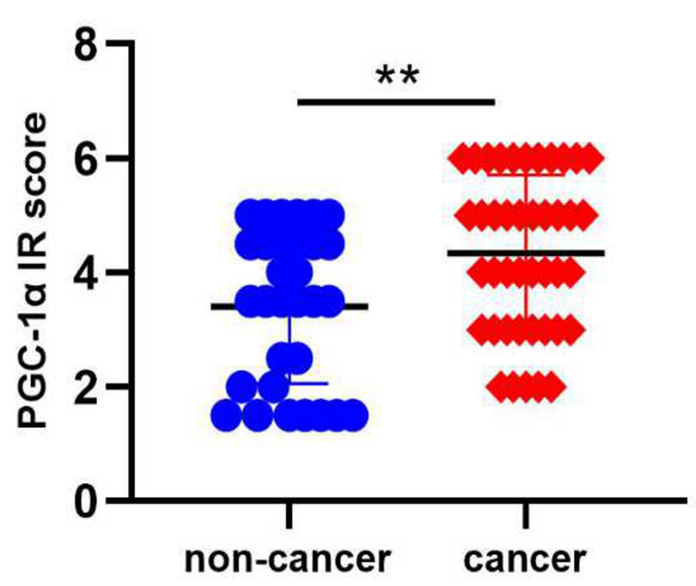

C
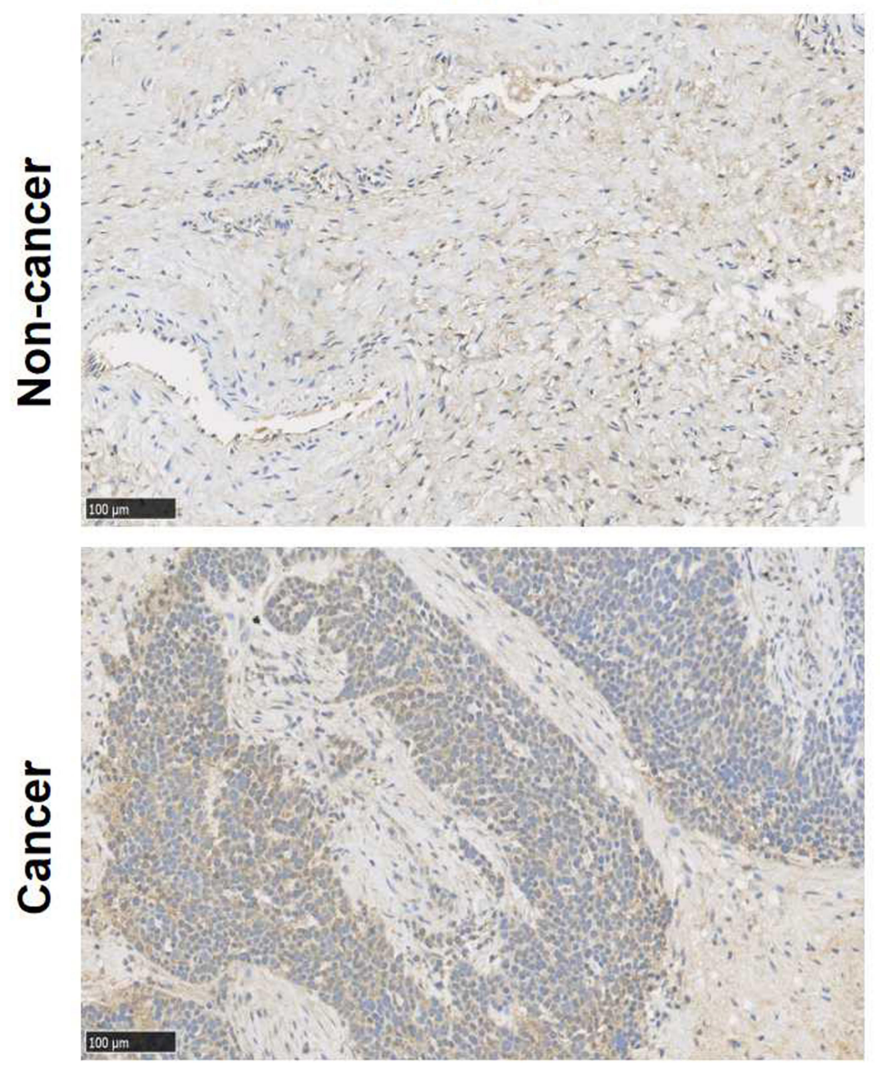

B

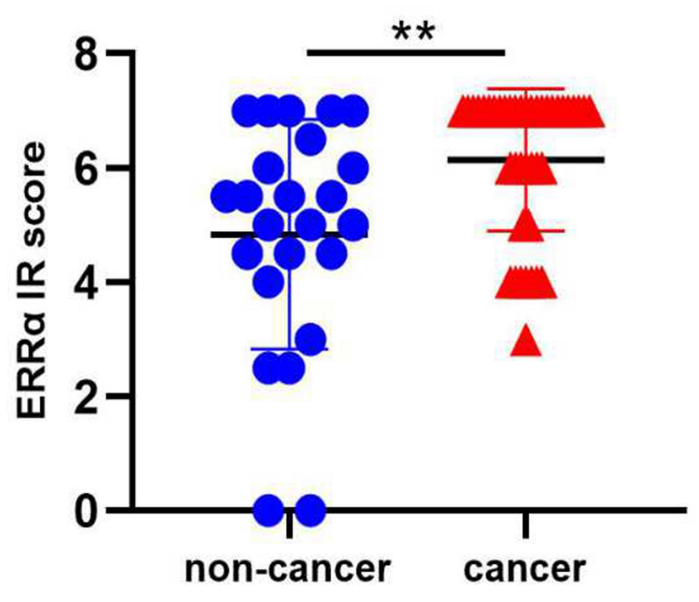

ERRa
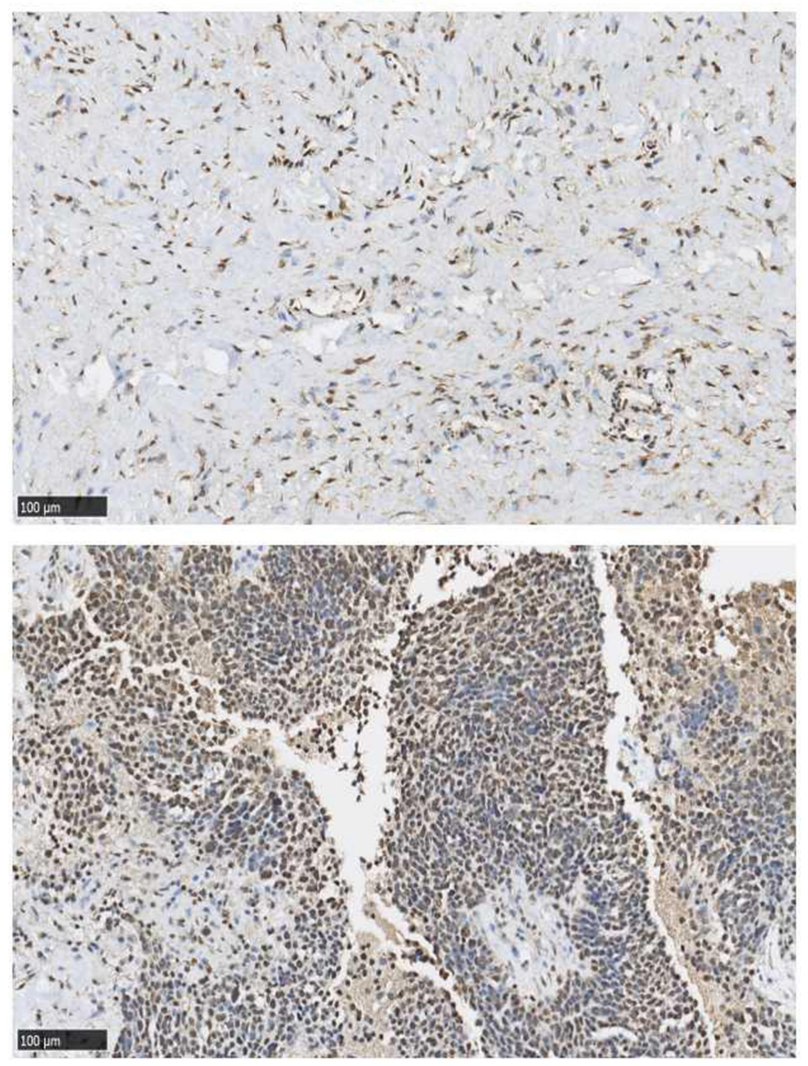

Figure 2 The expression of PGC-I $\alpha$ and ERR $\alpha$ in OC by IHC. (A and B) Ovarian tissues exhibited significantly higher PGC-I $\alpha$ and ERR $\alpha$ expression compared with noncancer ovarian tissues ( $P=0.0059, P=0.002)$. (C) PGC-I $\alpha$ and ERR $\alpha$ presented low expression in noncancer tissues while elevated PGC-I $\alpha$ and $E R R \alpha$ expression was recorded in the $O C$ tissues. Original magnification, $\times 200$.

Note: $* *$ p $<0.01$.

Abbreviations: ERR $\alpha$, estrogen-related receptor $\alpha$; IHC, Immunohistochemistry; IR score, immunoreactivity score; OC, ovarian cancer; PGC-I $\alpha$, peroxisome proliferatoractivated receptor gamma coactivator I-alpha.

Numerous studies have focused on the potential mechanism of action of PGC-1 $\alpha / E R R \alpha,{ }^{31-33}$ and multiple potential novel agonists have been identified, such as genistein, apigenin, resveratrol, daidzein, flavone, and cholesterol. ${ }^{18,34-36}$ Our latest research detected ERR $\alpha$ levels in uterine tumors by IHC and found that high expression of ERR $\alpha$ is associated with myometrial invasion. In addition, we identified a novel role for PGC-1 $\alpha$ and ERR $\alpha$ as positive regulators of EMT, 
Table I Association Between PGC-I $\alpha /$ ERR $\alpha$ Expression and Clinicopathological Parameters in Patients with Ovarian Cancer

\begin{tabular}{|c|c|c|c|c|c|c|c|c|c|c|c|c|c|}
\hline \multirow[t]{2}{*}{$\begin{array}{l}\text { Clinical } \\
\text { Features }\end{array}$} & \multirow[t]{2}{*}{$\begin{array}{l}\text { Total } \\
\text { (n) }\end{array}$} & \multicolumn{2}{|c|}{$\begin{array}{l}\text { PGC-I } \alpha \\
\text { Expression }\end{array}$} & \multirow[t]{2}{*}{$\chi^{2}$} & \multirow[t]{2}{*}{$\mathbf{P}$} & \multicolumn{2}{|c|}{$\begin{array}{l}\text { ERRa } \\
\text { Expression }\end{array}$} & \multirow[t]{2}{*}{$\chi^{2}$} & \multirow[t]{2}{*}{$\mathbf{P}$} & \multicolumn{2}{|c|}{$\begin{array}{l}\text { PGC-I } \alpha / \text { ERR } \alpha \\
\text { Expression }\end{array}$} & \multirow[t]{2}{*}{$\chi^{2}$} & \multirow[t]{2}{*}{$\mathbf{P}$} \\
\hline & & High & Low & & & High & Low & & & $\begin{array}{l}\text { High/ } \\
\text { High }\end{array}$ & $\begin{array}{l}\text { Neither } \\
\text { High }\end{array}$ & & \\
\hline $\begin{array}{l}\text { Age, years } \\
\quad<55 \\
\quad \geq 55\end{array}$ & 42 & $\begin{array}{l}17 \\
12\end{array}$ & $\begin{array}{l}8 \\
5\end{array}$ & 0.032 & 0.859 & $\begin{array}{l}15 \\
11\end{array}$ & $\begin{array}{l}10 \\
6\end{array}$ & 0.095 & 0.758 & $\begin{array}{l}11 \\
7\end{array}$ & $\begin{array}{l}14 \\
10\end{array}$ & 0.033 & 0.856 \\
\hline $\begin{array}{l}\text { Tumor size, cm } \\
\quad<10 \\
\geq 10\end{array}$ & 41 & $\begin{array}{l}21 \\
8\end{array}$ & $\begin{array}{l}5 \\
7\end{array}$ & 3.459 & 0.063 & $\begin{array}{l}17 \\
9\end{array}$ & $\begin{array}{l}9 \\
6\end{array}$ & 0.119 & 0.73 & $\begin{array}{l}13 \\
5\end{array}$ & $\begin{array}{l}13 \\
10\end{array}$ & 1.073 & 0.3 \\
\hline $\begin{array}{l}\text { Tumor } \\
\text { differentiation } \\
\text { Well, moderate } \\
\text { Poor }\end{array}$ & 37 & $\begin{array}{l}6 \\
18\end{array}$ & $\begin{array}{l}8 \\
5\end{array}$ & 4.786 & 0.029 & $\begin{array}{l}6 \\
19\end{array}$ & $\begin{array}{l}8 \\
4\end{array}$ & $6.275^{\mathrm{a}}$ & 0.027 & $\begin{array}{l}3 \\
14\end{array}$ & $\begin{array}{l}11 \\
9\end{array}$ & $5.45 \mathrm{I}^{\mathrm{a}}$ & 0.04 \\
\hline $\begin{array}{c}\text { FIGO stage } \\
\text { I - II } \\
\text { III-IV }\end{array}$ & 41 & $\begin{array}{l}14 \\
15\end{array}$ & $\begin{array}{l}5 \\
7\end{array}$ & 0.149 & 0.699 & $\begin{array}{l}10 \\
15\end{array}$ & $\begin{array}{l}9 \\
7\end{array}$ & 1.036 & 0.309 & $\begin{array}{l}7 \\
11\end{array}$ & $\begin{array}{l}12 \\
11\end{array}$ & 0.717 & 0.397 \\
\hline $\begin{array}{l}\text { Lymph node } \\
\text { status } \\
\text { Absent } \\
\text { Present }\end{array}$ & 32 & $\begin{array}{l}13 \\
9\end{array}$ & $\begin{array}{l}8 \\
2\end{array}$ & $1.332^{\mathrm{a}}$ & 0.425 & $\begin{array}{l}10 \\
10\end{array}$ & $\begin{array}{l}11 \\
1\end{array}$ & $5.772^{\mathrm{a}}$ & 0.023 & $\begin{array}{l}5 \\
8\end{array}$ & $\begin{array}{l}16 \\
3\end{array}$ & $7.161^{\mathrm{a}}$ & 0.021 \\
\hline $\begin{array}{l}\text { CA I } 25, \mathrm{U} / \mathrm{mL} \\
\quad<78 \\
\quad \geq 78\end{array}$ & 42 & $\begin{array}{l}8 \\
21\end{array}$ & $\begin{array}{l}5 \\
8\end{array}$ & 0.497 & $0.48 \mathrm{I}$ & $\begin{array}{l}5 \\
21\end{array}$ & $\begin{array}{l}8 \\
8\end{array}$ & 4.388 & 0.036 & $\begin{array}{l}2 \\
16\end{array}$ & $\begin{array}{l}11 \\
13\end{array}$ & $5.802^{\mathrm{a}}$ & 0.021 \\
\hline $\begin{array}{l}\text { CAI53, U/mL } \\
\quad<14.8 \\
\quad \geq 14.8\end{array}$ & 38 & $\begin{array}{l}5 \\
20\end{array}$ & $\begin{array}{l}6 \\
7\end{array}$ & 2.844 & 0.092 & $\begin{array}{l}5 \\
19\end{array}$ & $\begin{array}{l}6 \\
8\end{array}$ & 2.085 & 0.149 & $\begin{array}{l}2 \\
14\end{array}$ & $\begin{array}{l}9 \\
13\end{array}$ & $3.635^{\mathrm{a}}$ & 0.078 \\
\hline $\begin{array}{l}\text { HE4, U/mL } \\
\quad<75.5 \\
\geq 75.5\end{array}$ & 34 & $\begin{array}{l}6 \\
19\end{array}$ & $\begin{array}{l}3 \\
6\end{array}$ & 0.296 & 0.67 & $\begin{array}{l}2 \\
17\end{array}$ & $\begin{array}{l}7 \\
8\end{array}$ & $5.625^{\mathrm{a}}$ & 0.025 & $\begin{array}{l}1 \\
13\end{array}$ & $\begin{array}{l}8 \\
12\end{array}$ & $4.568^{\mathrm{a}}$ & 0.05 \\
\hline
\end{tabular}

Notes: ${ }^{\text {a }}$ isher test was performed. The rest of the scores were from Chi-square test.

Abbreviations: ERR $\alpha$, estrogen-related receptor $\alpha$; PGC-I $\alpha$, peroxisome proliferator-activated receptor gamma coactivator I-alpha.

and showed that disruption of PGC-1 $\alpha / \mathrm{ERR} \alpha$ signaling could reverse EMT and inhibit endometrial cancer invasion and migration. $^{14}$

Currently, there are no reports in the literature on the analysis of PGC-1 $\alpha$ and ERR $\alpha$ expression in OC tissues by IHC. To verify the clinical significance of PGC-1 $\alpha / E R R \alpha$ expression in $\mathrm{OC}$, we first performed analyzed the mRNA levels of PGC-1 $\alpha$ and ERR $\alpha$ in OC tissues using data from the public database HPA. We found that patients with high ERR $\alpha$ mRNA expression had significantly lower OS rates compared with patients with low ERR $\alpha$ expression, which supported our prior observations. ${ }^{7}$ Similar trends were observed between PGC-1 $\alpha$ mRNA levels and patients with
OC in HPA. According to the central dogma of molecular biology, ${ }^{37}$ the sequential information transfer residue-byresidue, thus mRNA expression correlates to protein expression. Consistent with these results, immunohistochemical staining indicated that PGC-1 $\alpha$ and ERR $\alpha$ were remarkably overexpressed in $\mathrm{OC}$ tissues rather than in non-cancer ovarian tissues. We further investigated the correlation between PGC- $1 \alpha$ and ERR $\alpha$ expression and the clinical features of patients with OC. High ERR $\alpha$ expression was significantly associated with tumor differentiation, lymph node status, CA125, and HE4, whereas high PGC-1 $\alpha$ expression only significantly correlated with tumor differentiation. Moreover, Kaplan-Meier survival analysis revealed that the 
A

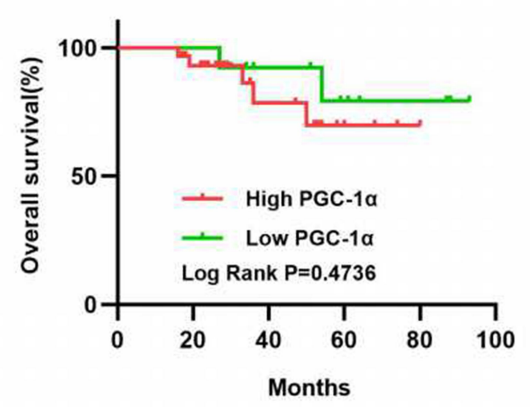

B

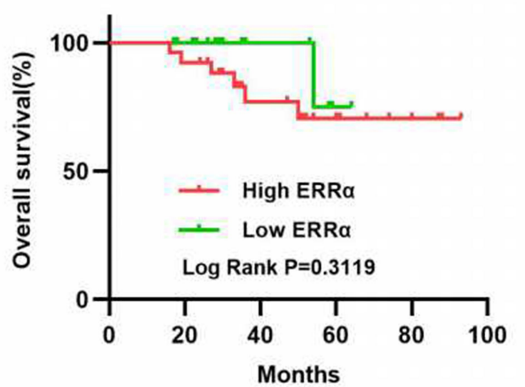

C

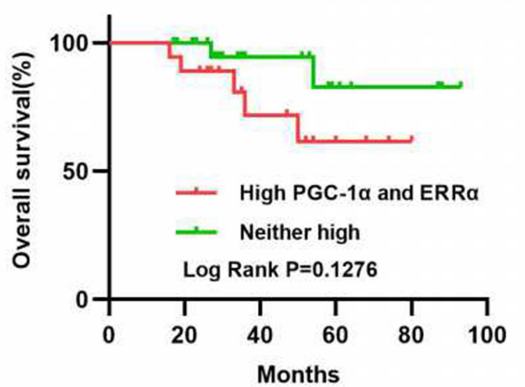

Figure 3 The prognostic significance of PGC-I $\alpha$ and ERR $\alpha$ in OC. (A and B) No significant relation was observed between PGC-I $\alpha$ and ERR $\alpha$ expression and the cancerspecific survival rate $(P=0.4736, P=0.3$ II9). (C) Combined analysis of high $P G C-I \alpha$ and ERR $\alpha$ expression tended to show poor cancer-specific survival $(P=0.1276)$. Abbreviations: ERR $\alpha$, estrogen-related receptor $\alpha$; OC, ovarian cancer; PGC-I $\alpha$, peroxisome proliferator-activated receptor gamma coactivator I-alpha.

prognostic value of PGC- $1 \alpha$ and ERR $\alpha$ in OC was not significant. Interestingly, combined analyses of the expression of the two proteins enhanced their clinical significance in OC as compared with the analysis of their expression alone. Poor differentiation and positive lymph node predict poor outcomes in OC. CA125 and HE4 are crucial biomarkers in the diagnostic and therapeutic monitoring phase. ${ }^{38}$ These data enhance the role of PGC-1 $\alpha$ and ERR $\alpha$ in the development and progression of ovarian cancer, as with what we observed in the experiments of cell lines and animals. ${ }^{22,23}$

This study has several limitations. Firstly, this is a retrospective study and might have selection bias. Secondly, our current study was based on small sample size and lack of adequate samples for further validation of protein biomarkers. Thirdly, future studies are necessary to address the mechanism that regulates the development and progression of OC.

\section{Conclusion}

In conclusion, the present study showed the expression and clinical significance of PGC-1 $\alpha$ and ERR $\alpha$ in human OC. The combined analysis of PGC- $1 \alpha$ and ERR $\alpha$ expression could be a useful prognostic indicator of OC.

\section{Abbreviations}

ERR $\alpha$, estrogen-related receptor alpha; HPA, Human Protein Atlas; IHC, Immunohistochemistry; OC, ovarian cancer; PGC-1 $\alpha$, peroxisome proliferator-activated receptor gamma coactivator 1-alpha.

\section{Acknowledgments}

This study was supported in part by grant YCXZ18-01 from Fujian Provincial Maternity and Children's Health Hospital, China.

\section{Disclosure}

The authors report no conflicts of interest in this work.

\section{References}

1. Kopper O, de Witte CJ, Lõhmussaar K, et al. An organoid platform for ovarian cancer captures intra- and interpatient heterogeneity. Nat Med. 2019;25(5):838-849. doi:10.1038/s41591-019-0422-6

2. Crevet L, Vanacker J-M. Regulation of the expression of the estrogen related receptors (ERRs). Cell Mol Life Sci. 2020;77:4573-4579. doi:10.1007/s00018-020-03549-0

3. Cai Q, Lin T, Kamarajugadda S, Lu J. Regulation of glycolysis and the Warburg effect by estrogen-related receptors. Oncogene. 2013;32 (16):2079-2086. doi:10.1038/onc.2012.221

4. Tennessen JM, Baker KD, Lam G, Evans J, Thummel CS. The Drosophila estrogen-related receptor directs a metabolic switch that supports developmental growth. Cell Metab. 2011;13(2):139-148. doi:10.1016/j.cmet.2011.01.005

5. Vernier M, McGuirk S, Dufour CR, et al. Inhibition of DNMT1 and ERR $\alpha$ crosstalk suppresses breast cancer via derepression of IRF4. Oncogene. 2020;39(41):6406-6420. doi:10.1038/s41388-020-01438-1

6. Zhou S, Xia H, Xu H, et al. ERR $\alpha$ suppression enhances the cytotoxicity of the MEK inhibitor trametinib against colon cancer cells. J Exp Clin Cancer Res. 2018;37(1):218. doi:10.1186/s13046-0180862-8

7. Sun P, Sehouli J, Denkert C, et al. Expression of estrogen receptor-related receptors, a subfamily of orphan nuclear receptors, as new tumor biomarkers in ovarian cancer cells. J Mol Med (Berl). 2005;83(6):457-467. doi:10.1007/s00109-005-0639-3

8. Gao M, Sun P, Wang J, Zhao D, Wei L. Expression of estrogen receptor-related receptor isoforms and clinical significance in endometrial adenocarcinoma. Int J Gynecol Cancer. 2006;16(2):827-833. doi:10.1111/j.1525-1438.2006.00527.x

9. Lynch C, Zhao J, Huang R, et al. Identification of estrogen-related receptor $\alpha$ agonists in the Tox 21 compound library. Endocrinology. 2018;159(2):744-753. doi:10.1210/en.2017-00658

10. Deblois G, St-Pierre J, Giguère V. The PGC-1/ERR signaling axis in cancer. Oncogene. 2013;32(30):3483-3490. doi:10.1038/ onc.2012.529

11. Chang C-Y, McDonnell DP. Molecular pathways: the metabolic regulator estrogen-related receptor $\alpha$ as a therapeutic target in cancer. Clin Cancer Res. 2012;18(22):6089-6095. doi:10.1158/1078-0432. CCR-11-3221

12. Villena JA, Kralli A. ERRalpha: a metabolic function for the oldest orphan. Trends Endocrinol Metab. 2008;19(8):269-276. doi:10.1016/ j.tem.2008.07.005 
13. Audet-Walsh É, Papadopoli DJ, Gravel S-P, et al. The PGC-1 $\alpha /$ ERR $\alpha$ axis represses one-carbon metabolism and promotes sensitivity to anti-folate therapy in breast cancer. Cell Rep. 2016;14(4):920-931. doi:10.1016/j.celrep.2015.12.086

14. Chen L, Mao X, Huang M, Lei H, Xue L, Sun P. PGC-1 $\alpha$ and ERR $\alpha$ in patients with endometrial cancer: a translational study for predicting myometrial invasion. Aging (Albany NY). 2020;12 (17):16963-16980. doi:10.18632/aging.103611

15. Uhlén M, Fagerberg L, Hallström BM, et al. Proteomics. Tissue-based map of the human proteome. Science. 2015;347 (6220):1260419. doi:10.1126/science.1260419

16. Pontén F, Jirström K, Uhlen M. The human protein atlas-a tool for pathology. J Pathol. 2008;216(4):387-393. doi:10.1002/path.2440

17. Liu G, Sun P, Dong B, Sehouli J. Key regulator of cellular metabolism, estrogen-related receptor $\alpha$, a new therapeutic target in endocrine-related gynecological tumor. Cancer Manag Res. 2018;10:6887-6895. doi:10.2147/CMAR.S182466

18. Willy PJ, Murray IR, Qian J, et al. Regulation of PPARgamma coactivator 1alpha (PGC-1alpha) signaling by an estrogen-related receptor alpha (ERRalpha) ligand. Proc Natl Acad Sci U S A. 2004;101(24):8912-8917. doi:10.1073/pnas.0401420101

19. Chisamore MJ, Cunningham ME, Flores O, Wilkinson HA, Chen JD, Bauer JA. Characterization of a novel small molecule subtype specific estrogen-related receptor alpha antagonist in MCF-7 breast cancer cells. PLoS One. 2009;4(5):e5624. doi:10.1371/journal. pone. 0005624

20. Vergara D, Merlot B, Lucot J-P, et al. Epithelial-mesenchymal transition in ovarian cancer. Cancer Lett. 2010;291(1):59-66. doi:10.1016/ j.canlet.2009.09.017

21. Loret N, Denys H, Tummers P, Berx G. The role of epithelial-tomesenchymal plasticity in ovarian cancer progression and therapy resistance. Cancers (Basel). 2019;11(6):838. doi:10.3390/ cancers 11060838

22. Wang C-W, Hsu W-H, Tai C-J. Antimetastatic effects of cordycepin mediated by the inhibition of mitochondrial activity and estrogenrelated receptor $\alpha$ in human ovarian carcinoma cells. Oncotarget. 2017;8(2):3049-3058. doi:10.18632/oncotarget.13829

23. Lam SS, Mak AS, Yam JW, Cheung AN, Ngan HY, Wong AS. Targeting estrogen-related receptor alpha inhibits epithelial-tomesenchymal transition and stem cell properties of ovarian cancer cells. Mol Ther. 2014;22(4):743-751. doi:10.1038/mt.2014.1

24. Zhao Y, Li Y, Lou G, et al. MiR-137 targets estrogen-related receptor alpha and impairs the proliferative and migratory capacity of breast cancer cells. PLoS One. 2012;7(6):e39102. doi:10.1371/journal. pone. 0039102

25. Stein RA, Gaillard S, McDonnell DP. Estrogen-related receptor alpha induces the expression of vascular endothelial growth factor in breast cancer cells. J Steroid Biochem Mol Biol. 2009;114(1-2):106-112. doi:10.1016/j.jsbmb.2009.02.010
26. Deblois G, Giguère V. Functional and physiological genomics of estrogen-related receptors (ERRs) in health and disease. Biochim Biophys Acta. 2011;1812(8):1032-1040. doi:10.1016/j. bbadis.2010.12.009

27. Eichner LJ, Giguère V. Estrogen related receptors (ERRs): a new dawn in transcriptional control of mitochondrial gene networks. Mitochondrion. 2011;11(4):544-552. doi:10.1016/j.mito.2011.03.121

28. LeBleu VS, O'Connell JT, Gonzalez Herrera KN, et al. PGC-1 $\alpha$ mediates mitochondrial biogenesis and oxidative phosphorylation in cancer cells to promote metastasis. Nat Cell Biol. 2014;16(10). doi:10.1038/ncb3039

29. Arany Z, Foo S-Y, Ma Y, et al. HIF-independent regulation of VEGF and angiogenesis by the transcriptional coactivator PGC-1alpha. Nature. 2008;451(7181):1008-1012. doi:10.1038/nature06613

30. Dwyer MA, Joseph JD, Wade HE, et al. WNT11 expression is induced by estrogen-related receptor alpha and beta-catenin and acts in an autocrine manner to increase cancer cell migration. Cancer Res. 2010;70(22):9298-9308. doi:10.1158/0008-5472.CAN-10-0226

31. Yan M, Audet-Walsh É, Manteghi S, et al. Chronic AMPK activation via loss of FLCN induces functional beige adipose tissue through PGC-1 $\alpha /$ ERR $\alpha$. Genes Dev. 2016;30(9):1034-1046. doi:10.1101/ gad.281410.116

32. Choi YK, Park JH, Baek -Y-Y, et al. Carbon monoxide stimulates astrocytic mitochondrial biogenesis via L-type Ca channel-mediated PGC- $1 \alpha /$ ERR $\alpha$ activation. Biochem Biophys Res Commun. 2016;479 (2):297-304. doi:10.1016/j.bbrc.2016.09.063

33. Craige SM, Kröller-Schön S, Li C, et al. PGC-1 $\alpha$ dictates endothelial function through regulation of eNOS expression. Sci Rep. 2016;6:38210. doi:10.1038/srep38210

34. Teng CT, Hsieh J-H, Zhao J, et al. Development of novel cell lines for high-throughput screening to detect estrogen-related receptor alpha modulators. SLAS Discov. 2017;22(6):720-731. doi:10.1177/ 2472555216689772

35. Wei W, Schwaid AG, Wang X, et al. Ligand activation of ERR $\alpha$ by cholesterol mediates statin and bisphosphonate effects. Cell Metab. 2016;23(3):479-491. doi:10.1016/j.cmet.2015.12.010

36. Teng CT, Beames B, Alex Merrick B, Martin N, Romeo C, Jetten AM. Development of a stable cell line with an intact PGC-1 $\alpha$ /ERR $\alpha$ axis for screening environmental chemicals. Biochem Biophys Res Commun. 2014;444(2):177-181. doi:10.1016/j.bbrc.2014.01.033

37. Strasser BJ. A world in one dimension: Linus Pauling, Francis Crick and the central dogma of molecular biology. Hist Philos Life Sci. 2006;28(4):491-512.

38. Potenza E, Parpinel G, Laudani ME, Macchi C, Fuso L, Zola P. Prognostic and predictive value of combined HE- 4 and CA-125 biomarkers during chemotherapy in patients with epithelial ovarian cancer. Int J Biol Markers. 2020;1724600820955195. doi:10.1177/ 1724600820955195
OncoTargets and Therapy

\section{Publish your work in this journal}

OncoTargets and Therapy is an international, peer-reviewed, open access journal focusing on the pathological basis of all cancers, potential targets for therapy and treatment protocols employed to improve the management of cancer patients. The journal also focuses on the impact of management programs and new therapeutic

Submit your manuscript here: https://www.dovepress.com/oncotargets-and-therapy-journal agents and protocols on patient perspectives such as quality of life, adherence and satisfaction. The manuscript management system is completely online and includes a very quick and fair peer-review system, which is all easy to use. Visit http://www.dovepress.com/ testimonials.php to read real quotes from published authors. 